Copyright (C) 2015 by Academic Publishing House Researcher

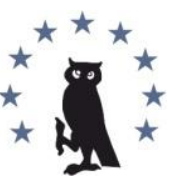

Published in the Russian Federation

European Researcher

Has been issued since 2010.

ISSN 2219-8229

E-ISSN 2224-0136

Vol. 92, Is. 3, pp. 172-184 2015

DOI: $10.13187 /$ er.2015.92.172

www.erjournal.ru

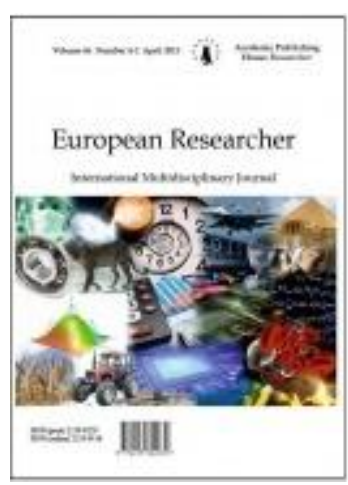

Historical sciences and archaeology

Исторические науки и археология

UDC 93(866)

\title{
The Museum-ship "Abdon Calderon"
}

\author{
Nicholas W. Mitiukov
}

International Network Center for Fundamental and Applied Research, Russian Federation

Dr. (Technical)

E-mail: nicoo2@mail.ru

\begin{abstract}
The paper deals the reconstruction of the career of the Ecuadorian tug "Abdon Calderon," which is now a museum-ship. It is shown that the ship had a significant impact on the naval history of Ecuador. But the role of the ship in the battle in the strait Jambeli in 1941 clearly exaggerated.

Keywords: naval; history; Ecuador; museum-ship.

\section{Введение}

История этого корабля началась в 80-х гг. XIX века, когда на верфи «Inch Yard» в Клайде заложили пароход водоизмещением в 300 тонн, разработанный компанией «David J. Dunlop \& Co». Это было самое заурядное судно, ничем не выделявшееся из более чем сотни собратьев, спроектированных этой компанией в период с 1881 по 1911 гг. В 1884 г. судно сошло на воду, а в спустя два года вошло в строй, пополнив собой парк буксирных пароходов компании «Adam Greulich у Cía.» из Вальпараисо (Чили) под наименованием «Чайуин» («Chaihuín»). В регистре компании он числился со следующими характеристиками: водоизмещение - 300 т., длина - 39,93 $\mathcal{M}$ (131 фут), ширина - 4,87 $\mathcal{M}$ (16 футов), осадка - 2,74 $\mathcal{M}$ (9 футов). Машина в 50 и.л.с. приводила в движение один винт, давая максимальную скорость 10,5 узлов. Но служба под чилийским флагом была недолгая.

Примерно в то же самое время, когда гсудноерой нашего повествования сошел на воду, в далеком Эквадоре произошла попытка государственного переворота. Но в отличие от предшественников, новые инсургенты выбрали нестандартную тактику. Понимая, что бой в чистом поле обречен на провал, они сделали ставку на «точечный» десант с моря (шаг впоследствии с блеском повторенный Фиделем Кастро). Повстанцы, арендовав в Панаме пароход «Алахуэла» («Alhajuela»), на его борту благополучно прибыли в Манаби. Для парирования удара правительству пришлось импровизировать, спешно вооружив подвернувшийся под руки пароход «Нуэбо де Хулио» («9 de Julio»).

Извлекая опыт из событий, президент Эквадора Х.М. Пласидо в декабре 1886 г. специальным указом выделил целых 11500 фунтов для «организации военно-морского
\end{abstract}


флота». Разумеется, говорить о приобретении на такую скромную сумму более-менее путного боевого корабля не приходилось, а вот на покупку вполне добротного только что построенного буксира «Чайуин» - вполне. Так бывший буксир свершено неожиданно для себя стал крейсером 3 ранга, по официальной эквадорской документации, или просто «крейсером», во всех остальных источниках.

Несмотря на такую явно популистскую классификацию, новое приобретение вполне соответствовало требованиям и задачам, которые могли бы перед ним возникнуть. Его вооружение преследовало задачу противостояния всякого рода инсургентам, зачастую вообще лишенных тяжелого вооружения, а размеры допускали транспортировку небольших групп десантников в любую точку эквадорского побережья, где даже взвод неожиданно появившихся правительственных сил мог в корне изменить события.

После вооружения на фактории «Ла Фама» в Гуаякиле, новоиспеченный крейсер вошел в строй эквадорского флота под наименованием «Котопакси» («Cotopaxi»), в честь вулкана и одноименной провинции. Его вооружение состояло из четырех 76-мм казнозарядных орудий Армстронга и двух картечниц Глатина (Glatin). Первым командиром крейсера стал капитан 2 ранга Н. Байона (Nicolás Bayona Ors), тот самый, что незадолго до этого отличился, командуя пароходом «Нуэбо де Хулио».

Первое десятилетие своей службы под эквадорским флагом «Котопакси» выполнял банальные обязанности корабля береговой обороны и транспорта, крейсируя в основном в районе Гуаякиля и реки Гайяс. Государственный переворот 1895 г. кроме смены правительства повлек и полную замену руководящих постов во флоте. Убежденный консерватор, Байона эмигрировал в соседнее Перу, где и умер в 1907 г. А новым командиром крейсера стал капитан 1 ранга Б. Кальдерон (Benigno S. Calderón).

Грандиозный пожар 1898 г., практически полностью уничтоживший Гуаякиль, как ни странно обошел стороной стоявший на якоре «Котопакси». Поэтому уже при либералах крейсер действительно смог стать ядром формировавшегося эквадорского флота. Опятьтаки в Чили, эквадорское правительство приобрело ряд кораблей, самым ценными и крупными из которых стали минный крейсер «Либертадор Боливар» («Libertador Bolívar», б. «Almirante Simpson») и миноносец «Тарки» («Tarqui»). В итоге, к 1910 г, когда запахло очередной войной с Перу, ВМС Эквадора уже более-менее могли за себя постоять.

Разногласия между Перу и Эквадором уходят своими корнями к началу XIX в., когда бывшие испанские колонии в Южной Америке добились независимости. Из-за того, что границы между новыми независимыми государствами совпадали с бывшими административными границами вице-королевств, бывшие братские народы с оружием в руках незамедлительно стали перекраивать карту в соответствии с национальными особенностями и потребностями.

Еще будучи в составе испанской империи, вице-королевства Перу и Великая Колумбия, имели на границе спорную провинцию Майянас, неоднократно передававшуюся туда и обратно. В итоге, в 1802 г. провинцию передали под управление перуанцам, так что при обретении обоими государствами независимости яблоко раздора было на лицо. Уже в 1828 г. перуанцы, отстаивая свои права на спорные территории, потерпели жестокое поражение от колумбийской армии под командованием маршала Сукре. Но проблемы при этом только обострились, поскольку уже в 1829-1830 гг. Великая Колумбия распалась на собственно Колумбию, Эквадор и Венесуэлу.

Новообразованное государство Эквадор, озабоченное стабилизацией собственных границ, незамедлительно подписало с Перу договор, по которому провинция Майянас делилась пополам. Тем не менее, вскоре Перу оспорило это соглашение, претендуя на всю провинцию целиком. Значение этого куска земли, сплошь покрытого джунглями, заключалось в том, что он включал в себя верховья Амазонки и, таким образом, контролировавшее его государство получало доступ к Атлантическому океану через территорию Бразилии.

В последующие сто лет эквадоро-перуанские отношения вылились в бесконечные споры, переговоры, арбитражи, пограничные разборки и инциденты. Подписывались многочисленные договоры, которые не ратифицировались. Дважды, в 1858 и 1882 гг. на границах происходили вооруженные конфликты. Кризис 1910 года - один из их числа. К счастью для Эквадора, его удалось уладить дипломатическими хлопотами США, Бразилии 
и Аргентины, так что новообразованный флот проявить себя не смог. Что интересно, все время кризиса «Котопакси» использовался исключительно как транспорт, доставляя к границе с Перу войска.

Зато уже на следующий год «Котопакси» удалось буквально переписать историю Эквадора. 5 января 1912 г. в наступившей анархии после смерти президента Эмилио Эстрады, доставленные на борту крейсера 315 человек батальона «Эсмеральдас» смогли установить новый порядок в Уйгре, Наранхито и Ягачи. Впрочем, вскоре инсургенты потерпели поражение, а все запятнавшие себя мятежом офицеры «Котопакси» были уволены в отставку. В результате этих пертурбаций пост командира крейсера занял капитан 2 ранга P. Андраде (Rafael Andrade Lalama), и в последовавшей затем более чем двухлетней гражданской войне, экипаж уже твердо стоял на стороне конституционного правительства. Впрочем, что интересно, правительство не сразу рискнуло вводить корабль в бой. В самый разгар борьбы за власть в 1912 г., «Котопакси» мирно провел в ремонте, меняя свои уже порядком изношенные котлы.

В сентябре 1913 г. командир «Котопакси» получил приказ перейти на север страны. 20 сентября корабль бросил якорь в Эсмеральдасе, где волею случая оказался в центре событий очередного мятежа. На рассвете 24 сентября полковник К. Конча (Carlos Concha Torres), командуя отрядом из 150 солдат, занял полицейские казармы Эсмеральдаса. Там инсургентам досталось почти семь десятков ружей, немедленно обращенные против правительства. Воодушевленные успехом, повстанцы атаковали казармы «Манаби», где элемент внезапности уже был утрачен, и они встретили ожесточенное сопротивление сил майора М. Вентимильи (Manuel Veintimilla). Видя тяжесть положения, Р. Андраде приказал поднять якорь и стать в непосредственной близости от казарм, чтобы держать под прицелом подступы к ним. Одновременно десантная партия в составе 22 матросов под командой мичмана M.M. Севальоса (Manuel María Cevallos) отправилась на помощь осажденным.

Видя затруднительность положения сухопутных сил, «Котопакси» сделал предупредительный выстрел из своего носового 76-мм орудия и отправил на берег еще одну десантную партию под командованием мичмана Х.T. Константе (Juan T. Constante). Последнее и решило исход дела - мятежники отступили. Признавая решительность действий командира «Котопакси», фактически спасшего положение, 3 октября он получил внеочередное воинское звание капитана 1 ранга.

В декабре 1913 г, после жестокого поражения правительственных сил в битве у Гуайябо, «Котопакси» смог буквально под носом у мятежников эвакуировать из Эсмеральдас свыше 600 деморализованных разгромом солдат. Опасаясь нежелательного развития событий, правительство организовало морскую блокаду Эсмеральдаса, сосредоточив там практически весь флот: «Котопакси», «Либертадор Боливар», транспорт «Конститусьон» («Constitución»), судно береговой обороны «Патрия» («Patria») и миноносец «Тарки».

Впрочем, победа мятежников была недолгой. Уже 10 февраля 1914 г. силами «Котопакси» и «Либертадор Боливар», правительственные силы приступили к бомбардировке Эсмеральдаса, а 25 февраля, после морского десанта с «Котопакси» и транспорта «Конститусьон» город пал, окончательно сломив силы кончистов, полностью капитулировавших к сентябрю.

В наступившей мирной жизни на «Котопакси» снова легли задачи судна береговой обороны и транспорта, попутно выполняя представительские функции. Так в 1917 г. крейсер выполнил роль военного эскорта судна «Патрия», на котором президент Б. Морено (Baquerizo Moreno) решил посетить удаленный форпост государства Галапагосские острова. 10 июля небольшая эскадра вышла из Гуаякиля, 21-го возвратившись в Эсмеральдас.

Этот вояж совпал с небольшим потеплением отношений с Перу. Так что сразу по возвращении, президент опять-таки в сопровождении «Котопакси» отбыл с визитом мира в Пуэрто-Писарро, куда корабли пришли 23 июля. Здесь их ждала перуанская эскадра, во главе с крейсером «Альмиранте Грау». После обмена традиционными любезностями с находившимся на его борту президентом Перу Хосе Прадо, последовал ответный визит в Гуаякиль. Лишь 29 июля, завершив взаимный обмен любезностями и мирными инициативами, но так и не достав из кармана кукиш, перуанский президент на крейсере убыл в Кальяо. 
Следующее десятилетие прошло для «Котопакси» более-менее спокойно. Из событий этого периода можно отметит лишь то, что в 1924-25 гг. по предложению капитана 1 ранга Андраде на борту крейсера проходили обучение гардемарины и кандидаты в инженеры флота. Среди первых был юноша Рафаэль Моран Вальверде, возглавивший корабль в 1940 г.

В 1928 г. «Котопакси» сменил свою классификацию, став, наконец, обычной канонерской лодкой. Интересно отметить, что подобное разжалование произошло в самый критический период существования эквадорского флота. Ведь именно в 1928 г. из-за навигационной ошибки был потерян минный крейсер «Либертадор Боливар», так что «Котопакси» на долгое время стал еще и крупнейшим боевым кораблем ВМС Эквадора. Справедливости ради следует отметить, что необходимость модернизации и перевооружения флота ясно осознавалась политическим руководством страны, но каждый раз находились более неотложные дела, связанные с экономическими и политическими кризисами. А в итоге на протяжении полутора десятков лет единственным кораблем свыше 100 тонн оставался «Котопакси».

Зато в 1936 г. в жизни канонерки произошли сразу два знаменательных события. Первое, в ходе ремонта ее перевели на жидкое топливо, а второе - смена названия. Отныне корабль получил имя Абдона Кальдерона, молодого лейтенанта смертельно раненого в бою у Пичинчи 24 мая 1822 г.

1938 г. принес обновленному кораблю литературную известность. В январе этого года французская писательница Паулетта Эверар Кейфер вместе со своим мужем художником Мануэлем Рендоном отправилась в путешествие на Галапагосские острова. В поисках уединения они попали на остров Флореана, насчитывавшего в то время всего 10 жителей. Каково же было удивление супругов, когда за ними не прибыл обещанный пароход, так что в течение четырех месяцев Рендоны смогли ощущать себя настоящими робинзонами. Спас молодую пару из неожиданного уединения «Абдон Кальдерон». В мае 1938 г. он под командованием капитана 3 ранга А. Вильягомеса (Aníbal Villagómez Yépez) обходил с обычным патрульным заданием Галапагосские острова. Так что на его борту Паулетта и Мануэль смогли возвратиться на большие острова и дальше в Гуаякиль. В итоге канонерке удалось попасть на страницы романа Паулетты де Рендон «Галапагос: Последний заколдованный остров».

Тем временем снова обострилась обстановка с Перу. В 1936 г. представители обоих государств встретились в Вашингтоне, чтобы в очередной раз попытаться решить вопрос о спорных территориях, но снова, проведя более года во взаимных упреках и нареканиях, делегации ни с чем разъехались по домам. Обстановка стала накаляться. В июне 1941 г. на границе в очередной раз произошла серия вооруженных инцидентов, в которых перуанцы, как водится, обвинили эквадорцев, а те, в свою очередь, перуанцев. Поскольку из-за полыхающей Второй мировой войны все внимание великих государств оказалось отвлеченным от проблем далеких джунглей, перуанские военные решили использовать сложившуюся обстановку, тем более что Эквадор в очередной раз находился на пороге гражданской войны. В обстановке политической нестабильности, президент Карлос Арройро дель Рио, опасаясь вооруженного выступления оппозиции, сосредоточил большую часть армии у столицы страны Кито. Таким образом, на юге общая группировка эквадорских войск не превышала, по разным данным, 1800-300о чел. (противостоящая ей перуанская группировка насчитывала до 15 тыс. чел.).

5 июля 1941 г. перуанская «Группа Север» под командованием генерала Элоя Уреты, общей численностью более 13 тыс. человек, при поддержке танкового батальона, довольно значительного количества артиллерии и авиации, вторглась в южную эквадорскую провинцию Эль-Оро и начала продвижение к Гуаякилю. В результате форменного «блицкрига» менее чем за месяц перуанцы заняли значительную часть южного Эквадора. A, например 31 июля, впервые в Америке, применив воздушный десант, захватили стратегически важный Пуэрто-Боливар. Впрочем, особого героизма в этой акции не было, поскольку еще 26 июля Эквадор объявил о прекращении огня. Одновременно перуанцы захватили спорные территории в Амазонии. Хотя 31 июля при международном посредничестве стороны заключили перемирие, отдельные стычки продолжались вплоть до октября. Кампания стоила перуанцам всего 107 убитых. Потери побежденных, как водится, никто не считал, но эксперты обычно оценивают их в 400-500 человек убитыми. 
29 января 1942 г. в Рио-де-Жанейро представители Эквадора и Перу подписали так называемый «протокол Рио». В обмен на вывод перуанских войск из страны, Эквадор отказался от более чем 200 тысяч км ${ }^{2}$ спорной территории, потеряв, таким образом, почти 40 \% своей площади и доступ к Амазонскому бассейну.

К началу эквадоро-перуанской войны 1941 г. главные силы флота Перу на Тихом океане состояли из крейсеров «Альмиранте Грау» и «Коронель Бологнези», эсминцев «Альмиранте Вильяр» и «Альмиранте Гуиссе», четырех подводных лодок типа R и ряда вспомогательных кораблей. Военно-морские силы Эквадора, как и его армия, также находились в режиме глубокой стагнации, насчитывая в своем составе лишь три небольших корабля, не способных никак противостоять своему грозному противнику. Как уже говорилось, самым мощным эквадорским кораблем этого периода и был «Абдон Кальдерон» под командой капитана 2 ранга Рафаэля Морана (Rafael Morán Valverde). Его вооружение составляли все те же два 76-мм орудия Армстронга, два 47-мм «мобилизованных» орудия, спешно поставленные на корабль в преддверии войны, годные, впрочем, лишь для салютов. Учитывая рост эффективности авиации, корабль также получил дополнительно два 20-мм зенитных автомата. Практически все боеприпасы 76-мм и 47-мм были произведены еще в XIX веке, так что среди них наблюдался необычайно высокий процент брака.

При подавляющем превосходстве над военно-морскими силами противника задачами перуанской эскадры определялись: охрана морского района, включая побережье до Сорритоса и пролив Хамбели; прикрытие приморского северного фланга армейской группировки; особо важно было воспрепятствование морским перевозкам неприятеля между провинциями Эль Оро и Гуаякиль, которые могли осуществиться через упомянутый пролив; бомбардировка военных объектов и укрепленных стратегически важных районов, таких, как очистительный завод в Вильяре. С объявлением войны, перуанская эскадра, выйдя из Кальяо, начала операции согласно этому списку.

Озабоченное отсутствием серьезных сил для противостояния перуанской агрессии в провинции Эль Оро, эквадорское командование принимает решение спешно перебросить туда подкрепления. Поскольку единственный возможный путь быстрой доставки пополнений был возможен только по морю, 23 июля морское командование получает приказ обеспечить перевозку войск из Гуаякиля в Пуэрто-Боливар. При подавляющем превосходстве перуанских сил на море, единственное разумное решение состояло в ночной проводке, и в 23 часа 24 июля в море вышли мотобот «Ольмедо» («Olmedo»), теплоходы «Пинта» («Pinta») и «Дэйси Эдит» («Daisy Edith») с 800 десантниками под охраной канонерской лодки «Абдон Кальдерон». В шесть утра следующего дня конвой был на месте. Разгрузка тех небольших сил, что смогли разместиться на этих трех пароходиках, продолжалась приблизительно четыре часа, пока в 10-25 (времена даны по бортовому журналу «Кальдерона» и рапорту его командира) над портом не появилась эскадрилья перуанских самолетов. Эквадорские данные отмечают, что целью налета были портовые сооружения и «Кальдерон», в это время пришвартованный к молу (в это трудно поверить, поскольку пароходы с войсками били гораздо более важной целью, чем какая-то старинная канонерка). Но, тем не менее, чтобы обеспечить себе свободу маневра под перуанскими бомбами, а также защитить гражданское население и постройки порта от случайных попаданий, якобы предназначавшихся «Кальдерону», Р. Моран принимает решение уйти из порта. Уже в море, неожиданно для себя в 11-15 на удалении 6 миль сигнальщики канонерской лодки обнаружили неизвестный корабль.

Тем временем, в результате авиационной разведки Пуэрто-Боливар, главком перуанского флота получил данные, что там находится эквадорский конвой с пополнением и снаряжением. Незамедлительно начальнику Северной группы поручалось организовать его перехват, который для этой цели отрядил находящийся в районе государственной границы у Пуэрто-Писарро эсминец «Альмиранте Вильяр».

Согласно записи в бортовом журнале (время взято по бортовому журналу «Альмиранте Вильяра» и рапорту его командира де Туделы), «Альмиранте Вильяр» покинул ПуэртоПиссаро в 07-29 этого дня и на скорости 14 узлов направился на север. В 10-55 он вошел в эквадорские территориальные воды, и на борту сыграли боевую тревогу. В 11-03 по носу был обнаружен корабль, пересекавший пролив Хамбели с юга на север. Наблюдение затрудняла 
сильная рефракция, так что невозможно было определить ни тип, ни национальную принадлежность обнаруженного судна, которое, кроме того, не несло национального флага. «Альмиранте Вильяр» увеличил скорость и сблизился на 6000 м. Судно вскоре идентифицировали как эквадорское, и, как позже узнали перуанцы, это и был «Абдон Кальдерон». После обнаружения «Альмиранте Вильяра», который эквадорцы спутали с более сильным «Альмиранте Гуиссе», канонерка повернула на $180^{\circ}$, подняла эквадорский боевой флаг и на всех парах стала отходить к берегу, к устью Хамбели.

В 11-19 «Альмиранте Вильяр» произвел предупредительный выстрел и дал право руля, чтобы ввести в действие артиллерию всего правого борта. Но, прежде чем маневр закончился, эсминец открыл огонь на поражение из 102-мм орудий № 1 и №2. Судя по рапорту командира «Альмиранте Вильяра» де Туделы, противник ответил лишь в 11-30 (но рапорт Морана утверждает, эквадорцы ответили в 11-20, то есть оба корабля начали бой одновременно). Скорость эсминца составляла 20 узлов, и он уже довольно близко подошел к берегу. В этом месте глубины были небольшие, так как берег представлял собой низменные речные заливные участки, и вероятность сесть на мель была очень велика. Поэтому командир приказал прекратить сближение и повернуть на $90^{\circ}$ влево, чтобы дать по неприятелю полный бортовой залп. В это время перуанские сигнальщики отметили попадание в носовую часть противника, "сопровождающееся выбросом больших клубов густого черного дьмма". Однако, судя по рапорту командира «Кальдерона», самые ближайшие снаряды противника падали в 20 м от корабля. Так что по всей вероятности перуанцы были введены в заблуждение поднятым со дна илом, тем более что глубины в этом месте небольшие.

Между тем эквадорцы продолжали отход и, во избежание посадки на мель, «Альмиранте Вильяр» должен был выполнить поворот на $180^{\circ}$, продолжая огонь левым бортом. Находясь на этом курсе, перуанские сигнальщики отметили еще одно «попадание» в противника, пока тот не скрылся в зарослях мангрового леса. Но «Альмиранте Вильяр» продолжал обстрел, используя теперь в качестве ориентира высокий столб черного дыма, валивший из трубы «Кальдерона», который явно показывал, что противник старается уйти от погони. В 11-40 де Тудела отдал приказ прекратить огонь. Командир принял решение выйти из боя, поскольку цель не была настолько ценной, чтобы подвергать опасности сесть на мель вверенный ему корабль.

Немного погодя был дан рапорт на «Коронель Бологнези», и в 11-50 получен ответ приказ возвращаться к Пуэрто-Писарро, что было выполнено, и эсминец занял место в струе крейсера. Оба корабля находились перед Пуэрто-Писарро до 15-оо.

Военно-морские силы Перу достаточно подробно проанализировали и изучили этот инцидент. В рапорте командира «Альмиранте Вильяра» отмечается: "Работа всего экипажа корабля во время акции была превосходна. Наши командиры, офицеры и матросы в течение всего боя действовали с большим воодушевлением, демонстрируя под огнем противника свой высокий патриотический дух и дисциплину, четко выполняя все отданные приказы. Я, как командир корабля, счастлив был иметь под своим командованием столь превосходный экипаж". Но на самом деле, по перуанской точке зрения, ничего по-настоящему героического в этом бою не было, и влияния на ход конфликта он совершенно не оказал. Результаты можно скорее охарактеризовать как «сухая ничья». Ни один из противников не получил повреждений. «Альмиранте Вильяр» продолжил нормальное выполнение своих задач. «Кальдерону» пришлось немного потрудиться своими машинами на форсированном режиме, что, судя по рапорту его командира, привело к «неполадкам в котлах», вынужденных работать с большей нагрузкой. После боя канонерка была поставлена в ремонт, на который, согласно данным перуанской разведки, была запрошена сумма в 9985 сукре, но эквадорская сторона это не подтверждает.

И, тем не менее, как это водится, этот же инцидент, исход которого был совершенно очевиден, получил диаметрально противоположную интерпретацию в лагере противника. Очевидно, таким путем начинали формироваться эквадорские военно-морские традиции. Суть альтернативной эквадорской версии, весьма подробно освещенной в многочисленных статьях эквадорских военно-морских историков, сводится к следующему - жестокая перестрелка нанесла страшные повреждения «Альмиранте Вильяру». 
В 11-15, когда «Абдон Кальдерон» шел курсом на север, и находился примерно в трех милях от маяка Хамбели, по левому борту был обнаружен корабль, идущий сходящимся курсом. Вдалеке виднелись дымы кораблей поддержки. Замеченный корабль увеличил ход и начал совершать маневрирование с явными признаками перерезать курс эквадорцам. Когда корабль сблизился, в нем опознали перуанский эсминец «Альмиранте Гуиссе», и в 11-25 капитан 2 ранга Моран приказал сыграть боевую тревогу. Одновременно противник выполнил поворот на правый борт, выходя на параллельный курс, и в 11-30 открыл огонь носовым орудием. Как только командир эквадорской канонерки увидел вспышку выстрела на неприятельском эсминце, он приказал открыть ответный огонь.

Схватка была абсолютно неравной, поскольку эквадорская канонерка могла рассчитывать лишь на два 76-мм и два 20-мм орудия. В дополнение ко всем несчастьям, после первого же выстрела кормовое 76-мм орудие вышло из строя. Тем не менее, за то недолгое время боя эквадорцы смогли поразить своего грозного противника 25 раз. Несколько 20-мм снарядов взорвались в надстройке, но наибольший вред нанесли четыре попадания 76-мм орудия.

Первое из них попало в предпоследнее орудие, полностью выведя его из строя, и ранив 9 человек расчета. Вторая бомба взорвалась на кормовом мостике, свалив бизань-мачту и повредив зенитное орудие. При этом, из-за падения мачты, два матроса получили смертельные ранения и поврежден торпедный аппарат. Еще один снаряд попал в левый борт на уровне ватерлинии прямо в торпедный погреб и повредил воздушный баллон одной из торпед, к сожалению, снаряд не взорвался, а его взрыв наверняка вызвал бы детонацию торпедных зарядов и привел бы если не к гибели, то тяжелым повреждениям перуанского эсминца. Четвертое попадание, по-видимому, вызвало пожар, или же перебило паропровод, поскольку после него эсминец окутался клубами густого дыма.

В 11-36 тяжело поврежденный эсминец противника вышел из боя. Эквадорцы тем временем были вынуждены укрыться в устье Хамбели, поскольку к месту боя подошли крейсер «Альмиранте Грау» и миноносец «Теньенте Родригес», взявшие на буксир своего тяжелоповрежденного собрата и доставившие его в Кальяо. В 11-45 эквадорцы прекратили огонь.

По окончании боя «Абдон Кальдерон» вернулся в Пуэрто-Боливар и в 12-11 бросил там якорь. Но передышка была недолгой, поскольку уже в 13-42 над портом появились неприятельские самолеты, по которым в течение примерно 15 минут стреляли зенитчики канонерки. В ожидании последующих налетов «Абдон Кальдерон» крейсировал перед портом до четырех вечера.

Таким образом, одно и тоже событие описывается обеими сторонами абсолютно поразному. Хотя, в эквадорской точке зрения наблюдается определенная нестыковка. Во-первых, по участвовавшим в ней перуанским кораблям. Официальные эквадорские источники очень быстро подкорректировали жертву неравного боя («Альмиранте Вильяр» вместо «Альмиранте Гуиссе»), но вот по остальным участникам вышла явная промашка. Так «Альмиранте Грау», судя по перуанской документации, в это время находился в сухом доке в Кальяо, заканчивая обработку своей подводной части, а «Теньенте Родригес» имел честь быть в Икитосе уже семь лет как исключенным из списков флота. Он использовался как топливная баржа в Амазонии! Дополнительную настороженность вызывает и тот факт, что практически сразу после боя «Кальдерон» перевооружили: вместо орудий Армстронга на него установили крупповские. Но ведь если пушки «Кальдерона» смогли дать 30 \% попаданий, то зачем их менять?

Несмотря на явную нелепость, эквадорская версия оказалась на диво живучей, причем настолько, что спустя десятилетия после безрезультатной стычки она вполне успешно переправилась через Атлантику и прочно обосновалась в исследованиях военно-морских историков Старого света. И даже более того, в свое время просочившись, благодаря польским публикациям, дружно принявшим на веру именно эквадорское видение «неравного боя», на просторы еще целого Союза. История о тяжело поврежденном «Альмиранте Вильяре» стала мучительной загадкой для многих отечественных флотских историков-любителей - ведь не только очевидная и вполне оправданная гордость за лучшие эскадренные миноносцы российского флота, но и элементарные логические выводы не позволяли допустить подобного исхода боя! В принципе, эквадорская трактовка в качестве 
истины в последней инстанции бытует и поныне, время от времени всплывая в различных изданиях.

Чтобы окончательно расставить все точки над $i$, попытаемся разобраться, а была ли хотя бы какая-нибудь вероятность эквадорской трактовки боя.

Встреча двух кораблей, когда их бою никто и ничто не мешает, довольно уникальна. В этой ситуации каждая из сторон может рассчитывать только на свои силы. Попытаемся разобраться, что же собой представляла артиллерия противоборствующих сторон. Перед нами пушки, почти ровесники друг друга. 102-мм русское орудие с длиной ствола 60 калибров и 76-мм орудие Армстронга. Результаты проведенного баллистического расчета показали, что на всех дальностях стрельбы русское орудие имеет более настильную траекторию. Во время боя дистанция изменялась от 6000 до $3000 \mathcal{M}$. На всех этих дистанциях, за счет лучшей баллистики, перуанцы имеют вероятности поражения выше в $2,3 \ldots 2,5$ раза. Если учесть, что орудий в бортовом залпе они также имеют в два раза больше (а при условии, что одно эквадорское орудие не стреляло, то и в четыре раза), то получается, что на каждое эквадорское попадание они должны были ответить пятью (или десятью).

Вопрос второй, могли ли перуанцы дать хотя бы одно попадание? Судя по рапорту перуанского командира, за 20 минут боя они выпустили 41 снаряд, что при вероятности попадания от 0,04 (на 6000 м) до 0,14 (на 3000 м) должно было бы гарантировать от 1 до 5 попаданий. При расчетах характеристики рассеяния были приняты как для Первой мировой войны. Отсюда можно сделать вывод, что за 8 лет, прошедших с момента приобретения эсминца в Эстонии перуанцы толком освоить материальную часть так и не смогли. Вероятно, причина этого кроется в недостатке снарядов, поскольку, как отмечается в рапорте де Туделы, во время боя использовались снаряды из партии, закупленной в Эстонии вместе с эсминцами (в рапорте они названы снарядами партии 1933 г.). А ведь еще по данным советской разведки было известно, что эстонцы испытывают жестокий дефицит снарядов для своей артиллерии!

И, наконец, вопрос третий, если принять на веру об якобы имевших место 4 попаданиях в перуанский эсминец, сколько же понадобилось времени для подобного расстрела? Предположим, что расстрел производится с дальности 3000 м. Вероятность попадания составляет 0,055, и таким образом получается, что надо выстрелить около 72 раз. Даже если эквадорцы бы давали по два выстрела в минуту, им бы пришлось стрелять около 40 минут!

Автор далек от утверждения истин в последней инстанции, и эквадорское видение этого боя также нельзя сбрасывать со счетов, однако как явствует из проведенного исследования, его вероятность намного ниже, чем перуанская точка зрения.

Тем не менее, сражение в Хамбели обессмертило «Абдон Кальдерон» во флоте Эквадора. Мог ли конструктор «Кальдерона» Девид Данлоп, скончавшийся в 1911 г. даже в самых отчаянных мечтах предвидеть такой успех своего творения! Но, тем не менее, его пароход постепенно пройдя путь от буксира до крейсера и далее до войскового транспорта, судна береговой обороны, учебный корабль, в итоге превратился в музей.

\section{Заключение}

По окончании Второй мировой войны США начали усиленно снабжать ставшими ненужными боевыми кораблями государства Латинской Америки. Правительство Эквадора также не упустило возможности перевооружить свои ВМС. Первым большим приобретением в 1947 г. стал фрегат «Гайяс» («Guayas», б. PF-56 «Covington» типа «Тасота») водоизмещением 1190 т., а последним в 1954-м - два британских эсминца типа «Hunt», доведя общее количество крупных единиц до двенадцати. «Абдон Кальдерон», хоть и продолжал оставаться в строю, постепенно понижается в классе и отходит от дел. В 1950 г., приняв классификацию и организацию ВМС США, «Абдон Кальдерон» получил к названию приставку «BAE» (Buque de la Armada del Ecuador - корабль ВМС Эквадора). Последней значащей датой для корабля стало 16 июля 1960 г., когда Приказом № 12 его исключили из списков военно-морских сил. В течение нескольких последующих лет бывший крейсер пребывал на приколе в реке Гайяс в Гуаякиле, пока в 1972 г. не началось строительство морского музея рядом с территорией военно-морской базы. В 1986 г. «BAE Abdón Calderón» принял на борт первых посетителей. 


\section{References:}

1. Aray Arteaga V. BAE Calderón. 74 Años de historia Naval del Ecuador // http://www.ecua.net.ec/ baecalderon, 2003.

2. El heroico David ecuatoriano de siempre frente al poderoso Goliat peruano. Combate naval de Jambelí, año 1941 // http://antiperuano.8k.com/menu_nacionalista_ecuador.htm.

3. Rodriguez J. Los destructores "Almirante Guise" y "Almirante Villar" comprados a Estonia en 1933 // Revista de Marina. - Noviembre-Diciembre. 1994. № 6. P. 25-33.

4. Tudela-y-Laval H. Parte del Combate de Jambelí 25 Julio 1941. // № 0.200-17 (secreto)

5. Valdizan J. Jambelí: breve estudio histórico // Revista de Marina. Enero-Abril. 1985. Vol. 374. № 1. P. 6-26

6. Барабанов М. Вооруженный конфликт между Перу и Эквадором // Экспорт Вооружений. 2002. № 5. С. 47-56.

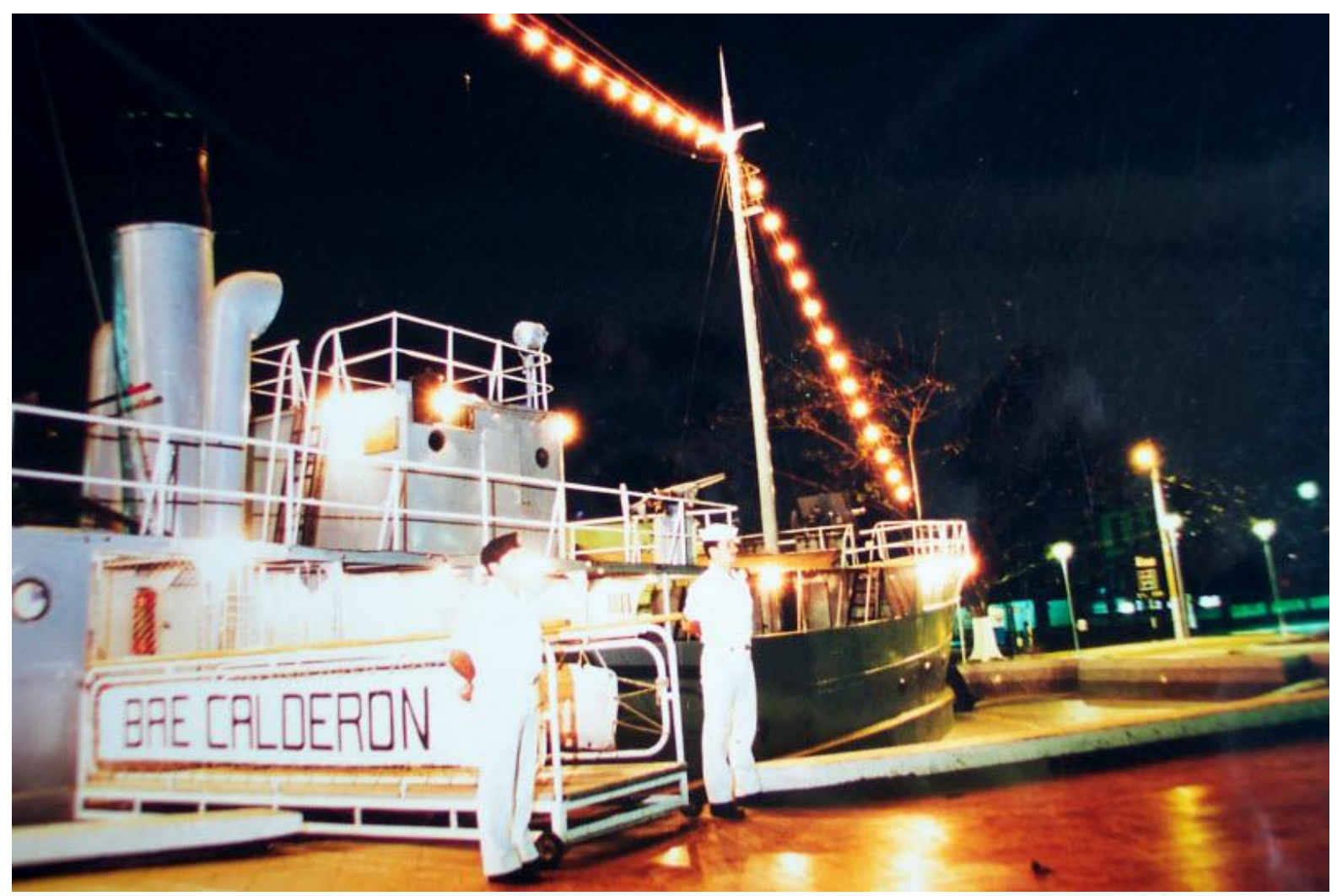

Корабль-музей ночью 


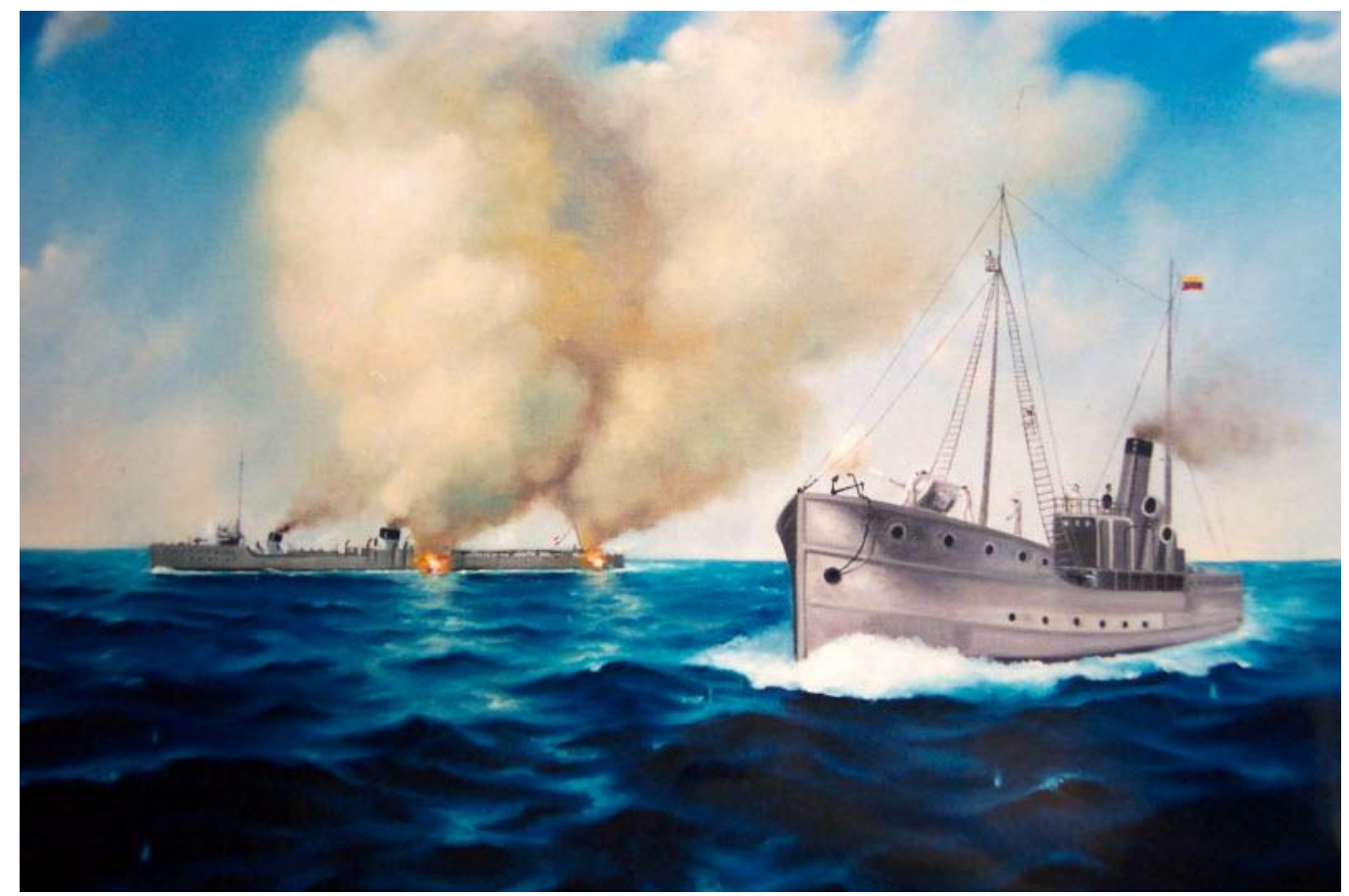

Одна из патриотических эквадорских открыток сражения в проливе Хамбели. На переднем плате - "Абдон Кальдерон"

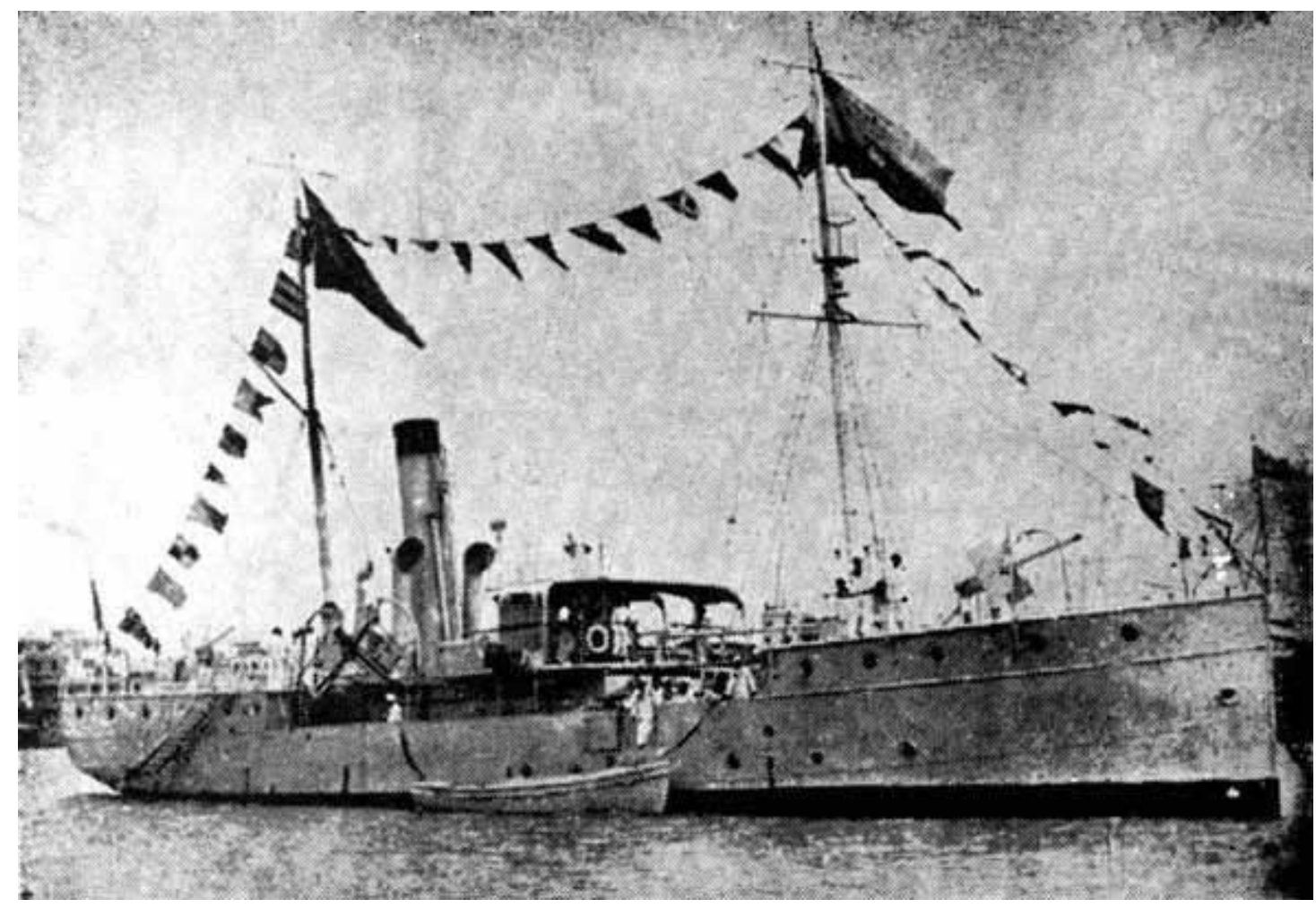

"Абдон Кальдерон" во время службы 


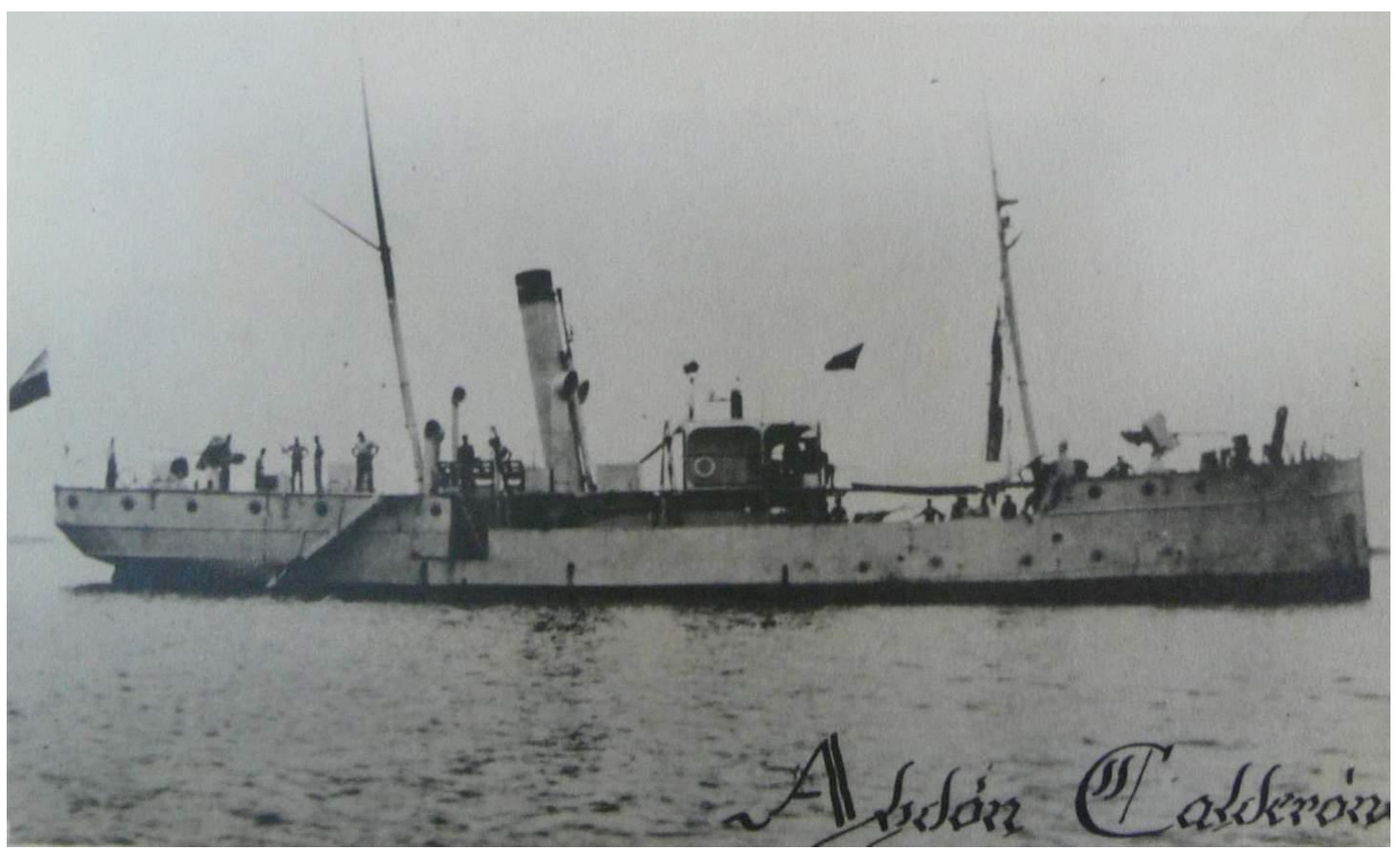

"Абдон Кальдерон" в 1930-е годы

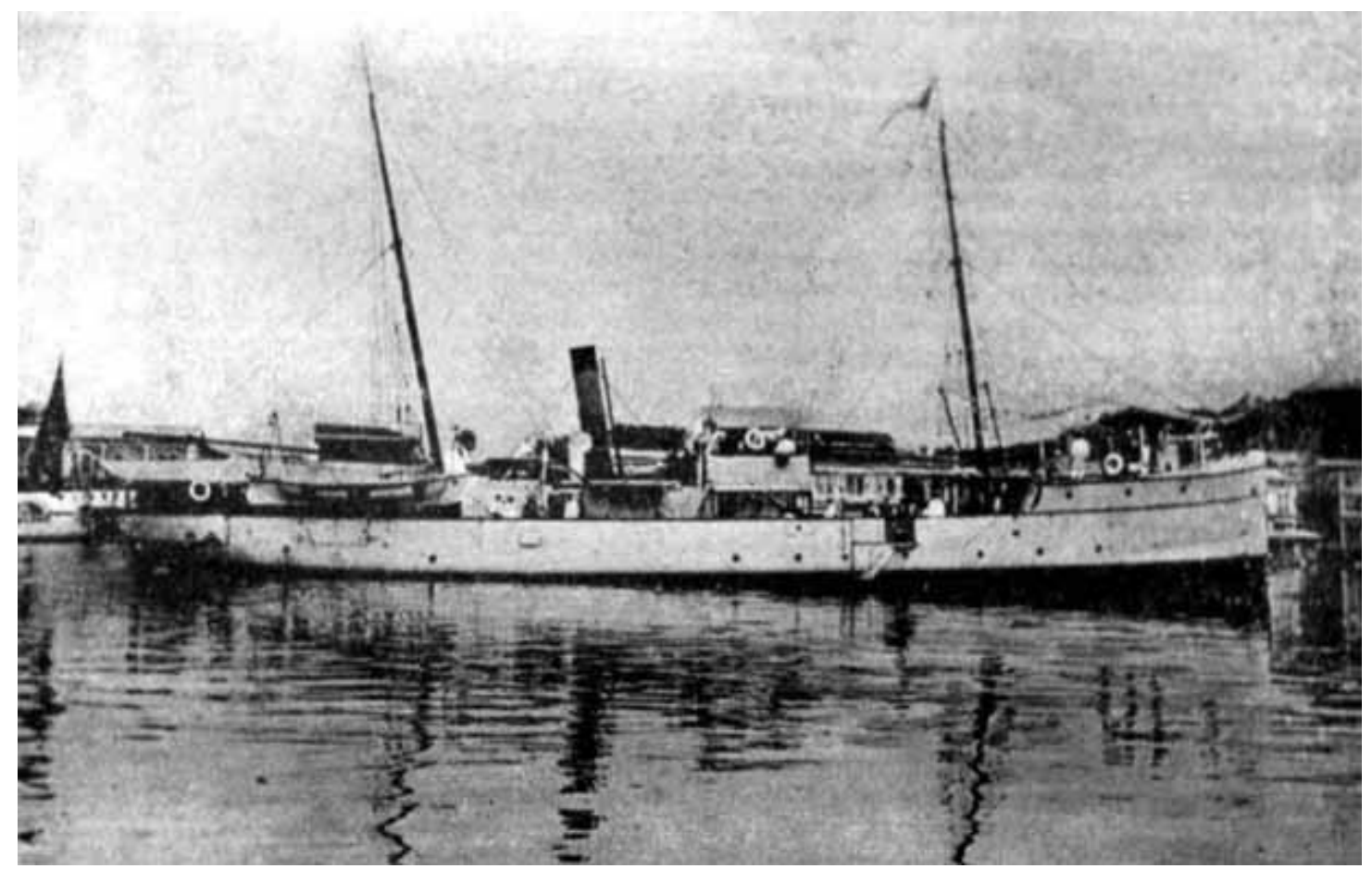

Вид во время службы 


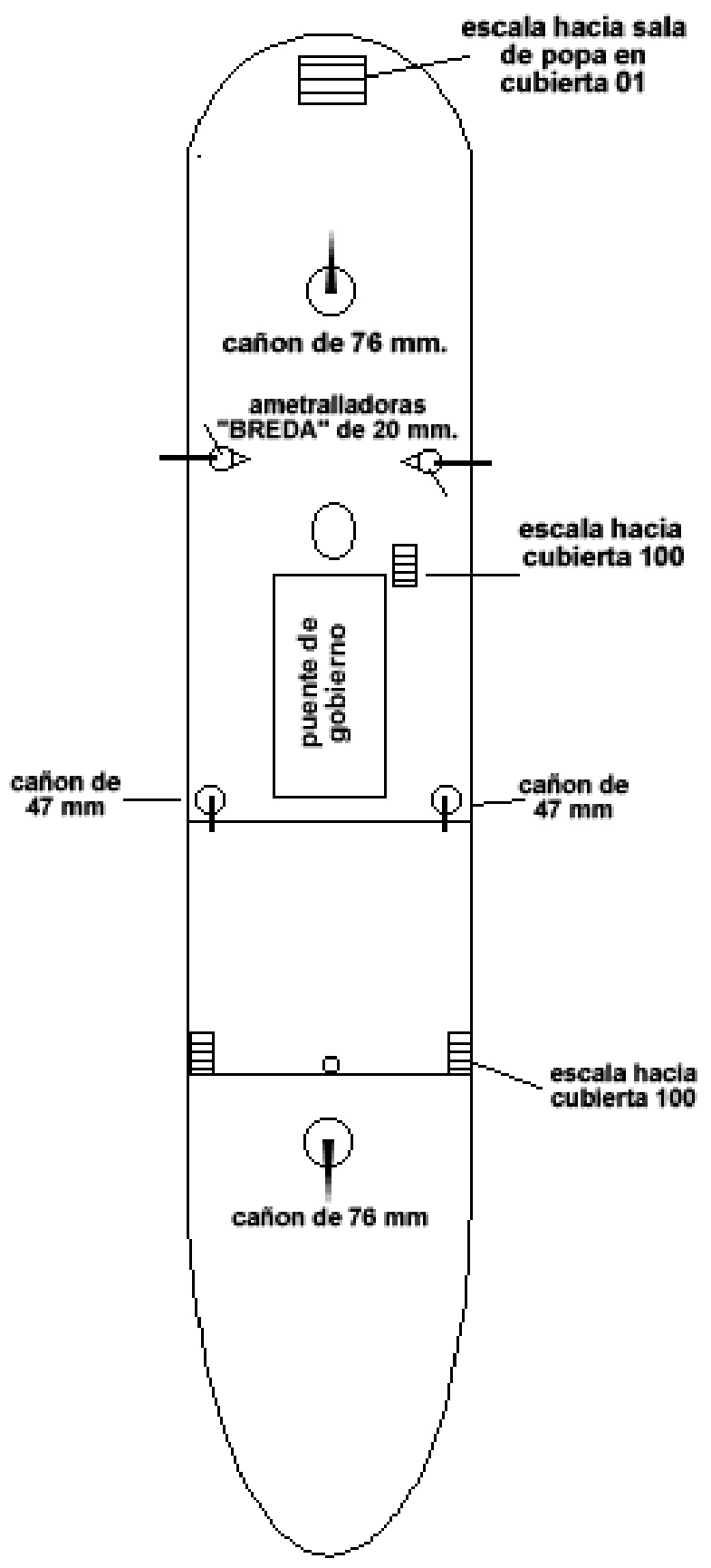

Parte Exterior

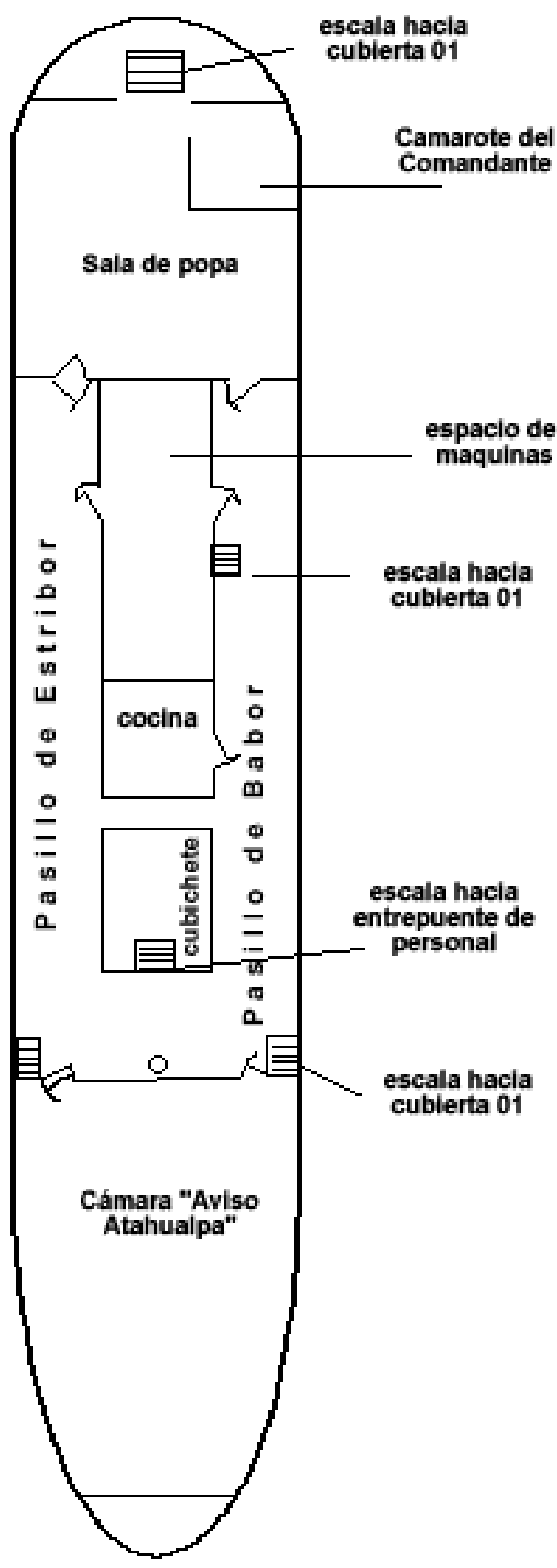

Parte Interior

Схема верхней и нижней палубы 
УДК 93(866)

\section{Корабль-музей «Абдон Кальдерон»}

Николай Витальевич Митюков

Международный сетевой центр фундаментальных и прикладных исследований, Российская Федерация

Лаборатория военных исследований

Доктор технических наук, профессор

E-mail: nico02@mail.ru

Аннотация. В работе проводится реконструкция карьеры эквадорского буксира "Абдон Кальдерон", который в настоящее время является кораблем-музеем. Показано, что судно оказало существенное влияние на военно-морскую историю Эквадора. Но роль судна в сражении в проливе Хамбели в 1941 г. явно преувеличена.

Ключевые слова: военно-морской флот; история; Эквадор; корабль-музей. 